\title{
ДЕЯКІ АСПЕКТИ ВИЗНАЧЕННЯ, РОЗУМІННЯ ТА ПРАКТИЧНОГО ЗАСТОСУВАННЯ ТЕАТРАЛЬНОГО ТЕРМІНА «ТЕМПО-РИТМ»
}

У статті розглянуто та висвітлено коло питань, які стосуються театрального терміна «темпо-ритм». Висновки та рекомендації трунтуються на енциклопедичних визначеннях та практичних розробках визначних майстрів сиени. Для практичного оволодіння окремими поняттями «темпо-ритму» використано драматургічний матеріал з доробку класиків украӥнської літератури. Автор наголошує на тому, щзо теоретичне та практичне засвоєння всього комплексу творчих дій, пов'язаних з темпо-ритмом, є необхідною та важливою складовою сучасного навчального процесу театральних закладів освіти.

Ключові слова: темпо-ритм сценічної дї̈, темпо-ритм вистави, композиџійна вибудова подій, емоиійні та смислові акценти, домінантна обставина, перморядні події n'єси.

В статье рассмотрен и освещен круг вопросов, касаюшихся театрального термина «темпо-ритм». Выводы и рекомендации основываются на энциклопедических определениях и практических разработках выдающихся мастеров сиены. Для практического овладения отдельными понятиями «темпо-ритма» использован драматургический материал из наследия классиков украинской литеpатуры. Автор отмечает, что теоретическое и практическое освоение всего комплекса творческих действий, связанных с темпо-ритмом, является необходимой и важной составляющей современного учебного процесса театральных учебных заведений.

Ключевые слова: темпо-ритм сиенического действия, темпо-ритм спектакля, композиционное построение событий, эмоциональные и смысловые акиенты, ведущее предлагаемое обстоятельство, первостепенные события пьесы.

In the article the circle of questions concerning the theatrical term «tempo-rhythm» is considered and covered. Conclusions and recommendations are based on encyclopedic definitions and practical developments of outstanding stage masters. For practical mastering of certain concepts of "tempo-rhythm», a dramatic material from the heritage of the classics of Ukrainian literature is used. The author notes that the theoretical and practical mastering of the whole complex of creative activities related to the tempo rhythm is a necessary and important component of the modern educational process of theatrical educational institutions.

Key words: tempo-rhythm of scenic action, tempo-rhythm of the performance, compositional construction of events, emotional and semantic accents, leading the proposed circumstance, the primary events of the play.

Про темпо-ритм написано багато і практиками сцени, і теоретиками театру. Мета статті - зосередитись саме на конкретизації понять і положень даної теми для залучення до практичного використання у навчальному процесі. Тобто здійснюється спроба певного свідомого відбору теоретично обгрунтованих і підтверджених практикою висновків і положень, оминаючи ускладнення та широту діапазонів висновків різного змісту та походження.
Автор має надію на те, що стаття буде цікавою і корисною тим, хто займається професійним вихованням майбутніх режисерів та акторів драматичного театру.

У різноманітних сферах людської діяльності поняття ритму і темпу існують окремо. Великий тлумачний словник сучасної української мови дає поняттю темп таке визначення: 1. Ступінь швидкості виконання музичного твору. // Ступінь швидкості виконання танцю, художнього 
читання тощо. // Ступінь швидкості вимовляння слів у мовному потоці. // У спорті - ступінь швидкості розмірених або повторюваних рухів, 3 яких складається та чи інша вправа. 2. Швидкість здійснення, виконання або інтенсивність розвитку чого-небудь. // Швидкість перебігу дії, процесу, явища $[1,1440]$. У цьому ж словнику поняття ритм має таке визначення: 1 . Рівномірне чергування впорядкованих елементів (звукових, мовних, зображальних і т. ін.), циклів, фаз, тих чи інших процесів і явищ. // муз. Чергування і співвідношення довгих і коротких долей і акцентів. 2. перен. Розміреність, злагодженість у протіканні чогось $[1,1223]$. Ці визначення допоможуть нам надалі більш точно і предметно означити параметри термінів, що стосуються теми дослідження.

Оскільки поняття та визначення темпу і ритму раніше сформувалось у галузі теорії та практики музики, $є$ сенс звернутися до музичної енциклопедії, яка дає таке визначення: «Темп (італ. tетро, лат. tempus - час) - швидкість розгортання муз. фактури твору в процесі його виконання або відчуття внутрішнім слухом; визначається кількістю метричних долей, які проходять за одиницю часу (переклад наш - A. 3.)» $[2,491]$.

Щодо поняття ритм, маємо таке визначення:

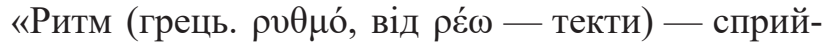
няття в часі форми перебігу будь-яких процесів. Різноманіття виявів ритму в різних видах і стилях мистецтва (не лише часових, а й просторових), а також за межами художньої сфери (ритм мови, ходи, трудових процесів і т. ін.) породило безліч суперечливих один одному визначень ритму (що позбавляє це слово термінологічної чіткості). У найширшому розумінні ритм - часова структура будь-яких процесів, що сприймаються, один 3 трьох (разом з мелодією і гармонією) основних елементів музики, який розподіляє відносно часу (за висловом П. І. Чайковського) мелодичні і гармонійні поєднання. Ритм творять акценти, паузи, членування на частки (ритмічні одиниці різних рівнів аж до окремих звуків), їх групування, співвідношення за тривалістю тощо; у вужчому значенні - послідовність тривалостей звуків, відмінна від їх висоти (ритмічний малюнок, на відміну від мелодичного). Естетичне значення ритму пояснюється організуючою дією та концентрацією уваги... У музиці таке розуміння ритму урівнюе його з рівномірним темпом або з тактом - музичним метром (переклад наш-A. 3.)» $[3,657]$.

«Але в музиці (так само, як і в поезіі), де роль ритму особливо важлива, його частіше протиставляють метру і пов'язують не 3 правильною пов- торюваністю, а з важко пояснюваним «відчуттям життя», енергією тощо («Ритм — це головна сила, основна енергія вірша. Пояснити його неможливо»,- В.В. Маяковський). Сутність ритму за Е. Куртом - устремління вперед, сконцентрований у ньому рух і наполеглива сила. На противагу визначенням ритму, які грунтуються на співвідносності (раціональності) і стійкій повторюваності (статиці), тут виділяється емоційна і динамічна природа ритму, яка може проявлятися без метра та бути відсутньою у метрично правильних формах (переклад наш - A. 3.)» [3, 657].

«Ритм переживається як зміна емоційних напружень та послаблень, які у точних маятникоподібних повторах зникають. У ритмі, таким чином, об'єднані статичні і динамічні ознаки, але, оскільки критерієм ритмічності залишається емоційна складова i, отже, значно суб'єктивна, межі, що відділяють ритмічні рухи від хаотичних і механічних, не можуть бути строго визначеними, що робить законним наведений вище підхід, який лежить в основі багатьох конкретних досліджень як мовного (у віршах і прозі), так і музичного ритму (переклад наш - A. 3.)» [3, 658].

Отже, ми переконуємось, що визначення термінів темп і ритм мають широку гаму нюансів і варіацій, що свідчить про виключно творчий зміст цих понять.

Звернімось до історії виникнення саме театрального терміна темпо-ритм. Темп і ритм об'єднав у єдине поняття К. С. Станіславський у процесі формування своєї системи виховання актора та режисера реалістичного театру. Реформатор театральної справи надавав великого значення впровадженню свого розуміння темпо-ритму як у навчальному процесі, так і в практиці театру. Погляди на сутність предмета нашого дослідження він виклав у розділі «Темпо-ритм», що увійшов до третього тому шеститомного видання 1954-1961 років. Розділ містить надзвичайно важливі визначення та висновки. Цитати будуть наведені нижче мірою розкриття суті досліджуваної теми.

Цей розділ містить 50 сторінок друкованого тексту і розрахований на проведення 16 групових практичних занять зі студентами, що в умовах сучасного навчального процесу зайняв би два місяці, тобто половину семестру. Такий об'єм матеріалу і тривалість часу, виділеного для засвоєння матеріалу свідчить про важливість теми для формування правильного розуміння природи творчого процесу реалістичного театру.

Треба зауважити, що цей розділ — це не опрацьована і вивірена частина до нової книги 
К. С. Станіславського, а лише підібрані матеріали, що надалі мали б стати основою теми, яка досліджує комплекс питань, присвячених темпо-ритму. Про кінцевий зміст розділу ми можемо лише здогадуватись. Але слід пам'ятати, що в останні роки творчого життя К. Станіславський намагався оформити систему у більш компактні форми i позбувався зайвого і надто складного у визначенні тих чи інших термінів. Автор системи розмежовував поняття темпо-ритму кожної окремої ролі, темпо-ритму сценічної дії, сценічної мови та темпо-ритму вистави в цілому. А саме: «У кожної людської пристрасті, стану, переживання свій темпо-ритм. Кожний характерний, внутрішній або зовнішній образ: сангвінік, флегматик, Городничий, Хлестаков, Земляника - має свій темпо-ритм. Кожний факт, подія відбуваються, безперечно, у відповідному їм темпо-ритмі (переклад наш-A. 3.)» $[4,152]$.

Театральна енциклопедія дає таке форму-

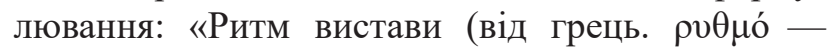
співмірність, виваженість) - узгоджений у часі i просторі рух, чергування і узгодженість усіх елементів і засобів виразності сценічної дії. Ритм пов'язаний $з$ наростанням або спадом, прискоренням або сповільненням, плавним перебігом або бурхливим розвитком дії. В даному випадку ритм немов зливається з темпом, поєднуючись із ним. Тому К.С. Станіславський застосував термін “темпо-ритм”, який об'єднує ці поняття. Він виявив складну взаємодію внутрішнього (відчуття актора, пов'язане з психологічним завданням, настроєм того чи іншого епізоду) темпо-ритму і зовнішнього (споглядуваного глядачем, втіленого в характерність, в рухах персонажа, в його поведінці). В одному і тому ж зовнішньому темпі можливі різні внутрішні ритмічні акценти... (переклад наш - A. 3.)» $[5,619]$.

Не обійшов увагою тему темпо-ритму і визначний режисер та реформатор українського театру Лесь Курбас. У своїх теоретичних викладах він не об'єднував поняття темп та ритм. Але в судженнях про природу ритму вистави, акторського існування у сценічному образі, ритму сценічного процесу український режисер має багато положень і висновків, що не суперечать узагальненням К. С. Станіславського, а в чомусь навіть доповнюють і розширюють їх практичне застосування. Лесь Курбас зазначав: «Мистецтво актора полягає в умінні тривати в чужому ритмі, тобто коли свої індивідуальні здатності, свій матеріал актор підпорядковує винайденому чужому ритмові. Підтягування чужого ритму під свій - не $\epsilon$ акторський спосіб, це є тривання в зовнішньому ритмі і є гра характеру» $[6,248]$.

Що ж стосується інших аспектів предмета цього дослідження, Лесь Курбас зауважував: «що основа основ у мистецтві це є ритм у широкому розумінні. Специфічність ритму ми бачимо, наприклад, і в нації, і в епосі, в геометричній формі-у всьому є свій ритм... Основа театрального мистецтва $\epsilon$ - просторовість, часовість і силовість. Просторове розподілення матеріалу, яке в собі містить часовість і силовість, і є мізансцена. Від ритму залежить, що саме 3 цих трьох моментів дійде до глядача» $[6,248]$. Тобто режисер наполягає на тому, що ритм дії та вистави в цілому важливий не лише для творця задуму та його виконавців, а й для глядача, який має сприйняти сценічну композицію драматургічного твору.

Поняттям темпо-ритм широко користуються у своїй практиці викладачі режисури драми та акторського мистецтва драматичного театру. Працюючи над роллю чи уривком з драматургічного твору, викладач рано чи пізно має познайомити студентів 3 поняттям темпо-ритму та навчити користуватися ним у практичній роботі. Особливо важливо донести до уваги студентів настанову К. С. Станіславського: «На розум безпосередньо впливають слово, текст, думка, уявлення, що викликають судження. На волю (бажання) безпосередньо впливають надзавдання, задачі, наскрізна дія. На почуття ж безпосередньо впливає темпо-ритм (переклад наш - $A$. 3)» $[4,187]$.

Деякі викладачі починають тренувати відчуття темпо-ритму на стадії виконання вправ та етюдів, чим значно полегшують засвоєння та подальше використання цього важливого засобу організації сценічної дії. Для визначення темпу сценічної дії достатньо градації з п'яти позицій, а саме: дуже повільний, повільний, середній, швидкий i дуже швидкий. Цих позицій абсолютно достатньо для використання в типових життєвих та сценічних ситуаціях. Більш розширена градація плутає студентів і ускладнює їх сприйняття даного питання. Кожну з цих градацій можна додатково характеризувати залежно від запропонованих обставин відповідним прикметником. Наприклад: темп середній розслаблений, темп швидкий напружений, темп повільний тривожний тощо.

Розглянемо конкретний випадок аналізу та побудови темпо-ритму уривка 3 драматургічного твору. Для цього дослідження добре підійде класична п'єса з гострим конфліктом, яскравими сценічними персонажами та змістовними подіями, а саме, драма «Олеся», що належить творчо- 
му доробку М. Л. Кропивницького. У першій яві першої дії служниця Горпина та чередник Павло прибирають горницю у панському будинку. Приготування пов'язані з іменинами господаря маєтку. Очікується візит поважних гостей. Час наближається до обіду. Ніщо не заважає дійовим особам виконувати свою роботу, вони діють злагоджено та уміло. Запропоновані обставини яви підказують, що дія має розвиватись у швидкому темпі. Для Павла сьогоднішній день - особливий. Його покликали в дім на допомогу у хатній роботі, а досі він служив чередником. Павло налаштований виявити себе 3 найкращого боку і стати лакеєм при господарях. Його завдання всім сподобатись, створити враження необхідності. Першою перепоною на шляху реалізації далекосяжного плану стає Горпина. 3 одного боку, вона може бути хорошою помічницею в майбутньому, а 3 іншого - недовірлива, непоступлива і самостійна у своїх судженнях і діях. Дію очолює Павло. Ява складається 3 декількох дієвих епізодів. Вони диктують зміни пристосувань і напрямів впливу, що в свою чергу творить ритмічний малюнок. Взаємодія відбувається у швидкому темпі, у ритмі посилення емоційного тиску Павла на опір Горпини. Зміна дієвих епізодів, пристосувань впливів та паузи формують темпо-ритм дії через реалізацію сценічного завдання.

У другій яві першої картини з'являється новий персонаж - господар маєтку Балтиз. Темп дії зразу змінюється зі швидкого на середній. Прислуга - люди залежні і безправні. Присутність хазяїна впливає на них гнітюче. Горпина не витримує напруження і під приводом пошуку віника втікає до іншої кімнати. Павло, користуючись відсутністю дівчини, пропонує Балтизу допомогу у його намірах звабити Горпину. Дію очолює Балтиз і різко відкидає будь-які пропозиції щодо своїх таємних намірів. Робить це він у декілька прийомів у дуже грубій формі, не даючи Павлові скористатися ситуацією. У цій яві темп взаємодії теж продиктований обставинами, а ритм творить дійова особа, яка очолює дію, через подолання неприйнятних для неї вчинків партнера. Зрештою господар дому дозволяє Павлу залишитись при горницях лакеєм, але встановлює чіткі межі його обов'язків і поведінки.

3 появою у наступній яві господині дому сценічна ситуація докорінно змінюється. Тепер дію очолює Лукерія Степанівна. Вона користується правом вирішувати, керувати, командувати. Будьякі самостійні дії хатніх робітників піддаються нещадній критиці і осуду. Вона вимагає від під- леглих абсолютно точного виконання своїх вимог, хоча вони часто безглузді. Дія відбувається у середньому темпі, а ритм задає персонаж, що очолює дію. Спілкування господині з прислугою важко назвати нормальним, оскільки вона увесь час ображає та принижує їх.

Робимо висновок, що темпо-ритм сценічної дії - це такий спосіб організації творчого процесу, при якому моменти посилення та послаблення напруження дії пов'язані з необхідністю та певними умовами вирішення того чи іншого сценічного завдання. До того ж, пам'ятаємо, що: «... правильно використаний темпо-ритм п'єси або ролі уже сам по собі, інтуїтивно, підсвідомо, часто механічно може оволодівати почуттям артиста і викликати точні переживання (переклад наш - $A$. 3.)» $[4,186]$.

Проаналізовані яви 3 першої дії драми М. Л. Кропивницького «Олеся» мають надзвичайно вигідні художні особливості, які з успіхом можна використати у практичній роботі зі студентами. У кожній з розглянутих яв змінюється дійова особа, що очолює дію. Це призводить до корінної зміни темпо-ритмів взаємодії та розвитку конфлікту. Оволодіння цим творчим процесом - важливе завдання для тих, хто хоче не лише розуміти природу темпо-ритму дії, а й засвоїти іiї практично. Пам'ятаємо про настанову К. Станіславського: «Якщо темпо-ритм вибудуваний правильно, то правильне почуття і переживання створюються природно, самі собою. Але якщо темпо-ритм хибний, то так само, на тому ж місці ролі народжуються неправильні для нас почуття і переживання, яких не можна виправити без зміни хибного темпо-ритму (переклад наш - $A$. 3.)» $[4,147]$.

Для вивчення аспекту темпо-ритму ролі звернемось до драми I. Я. Франка «Украдене щастя». У третій яві четвертої дії відбувається перший діалог між Анною і Миколою після повернення чоловіка 3 тюрми. Темп дії у третій яві визначають обставини: 1) - треба встигнути вирішити важке питання до приходу Михайла; 2) - у Миколи немає сил терпіти невизначеність свого становища. Тож темп, у якому розвивається дія, можна визначити як середній. Але маємо й інші обставини, а саме: розмова $є$ важкою чисто з психологічних міркувань. До визначення темпу дії як середній можна додати характеристику - напружений.

Ця сцена чітко ділиться на три дієві епізоди і визначення сценічного завдання в кожному з них не виявляє труднощів, якщо враховувати запропоновані обставини, що призвели до специфічних стосунків між дружиною і чоловіком. Змучений несподіваними негараздами, втратами, розчарова- 
ний Микола не втрачає надію повернути сімейне щастя і спокій. У першому дієвому епізоді герой щиро і проникливо умовляє Анну повернутись у сім'ю, забути про зраду і жити як раніше. Микола готовий пробачити дружині зраду і благає іiі повернутись до звичного сімейного життя. 3 одного боку, його намагання обгрунтовані і виважені, а 3 іншого - слабкі й безперспективні. Анна більше не кохає його і не має ні сил, ні бажання до примирення. Завдання повернути дружину стає нереальним і безглуздим. Тож у другому дісвому епізоді Микола змінює напрямок і мету зусиль. Він уже не просить, а вимагає від дружини дотримуватись хоча б зовні пристойності у своїй поведінці. А саме - не з'являтись разом з Михайлом привселюдно. Анна не сприймає та заперечує цю вимогу, бо не вважає свої стосунки аморальними. Вона щиро кохає Михайла і кохала його завжди. I в даному епізоді сценічне завдання вичерпує себе не на користь зрадженого чоловіка. У третьому дієвому епізоді третьої яви четвертої дії Микола усвідомлює, що втратив дружину остаточно. А от за свою чоловічу честь і людську гідність він має боротись не з Анною, а зі своїм кривдником. За змістом і значенням розглянута нами ява у структурній побудові п'єси є першорядною подією. Домінантна обставина цієї події — щире кохання Миколи до дружини. Це почуття утримує його від грубих випадів, звинувачень та засудження поведінки Анни. Сценічну дію у розглянутій події очолює Микола, тож і темпо-ритмічний малюнок ролі формується рішучими намаганнями змінити важку ситуацію 3 моментами слабкості і невпевненості у взаємодії 3 Анною. Позиція дружини у цьому протистоянні непохитна, хоч дається їй це непросто.

У четвертій яві четвертої дії драми «Украдене щастя» темпо-ритм сценічної дії змінюється. 3 приходом Михайла напруження у стосунках дійових осіб наростає. Темп сценічної дії швидкий. Гурман обмежений у часі і не має наміру відкладати побачення з Анною. Він очолює дію у спосіб нав'язування Миколі свого бачення і розуміння ситуації, яка склалась у результаті порушення моральних норм людського існування. Саме вчинки Михайла і творять ритмічний малюнок сцени, який полягає у тиску, висміюванні та залякуванні Миколи, у перешкоджанні останньому скористатись правом господаря дому та чоловіка своєї дружини. Ця ява за силою протистояння і глибиною змісту є першорядною подією п'єси, в якій Михайло для досягнення своєї мети застосовує фізичну силу до свого супротивника. Цим вчинком він переводить протистояння дійо- вих осіб п’єси в іншу площину, більш небезпечну і непередбачувану. Гурман не вірить, що Микола здатен на серйозний супротив. Ця обставина $є$ домінантою у події.

Робимо висновок, що темпо-ритм ролі - це здійснення ряду сценічних вчинків по лінії наскрізної дії, напруження та послаблення яких обумовлене запропонованими обставинами п'єси та способом взаємодії персонажів, тобто реалізацією сценічного завдання.

Розглядаючи питання темпо-ритму вистави, будемо спиратися на визначення К. С. Станіславського: «Темпо-ритм усієї п'єси - це темпо-ритм iii наскрізної дії і підтексту (переклад наш - $A$. 3.)» $[4,167]$. Оскільки наскрізна дія вистави реалізується через основний конфлікт, що відбувається у першорядних подіях п'єси, то зосередимо увагу на творчому задумові вистави. Він починається 3 аналізу всіх компонентів драматургічного твоpy: сюжету, обставин, подій, природи конфлікту, теми, ідеї, наскрізної дії та надзавдання. Наступний етап - це композиційна побудова подій, взаємин та взаємодії персонажів.

Як приклад визначення та формування темпо-ритму вистави пропоную звернутися до п’єси Л. Українки «Йоганна, жінка Хусова». Свій твір Л. Українка назвала драматичним етюдом, маючи на увазі цілу низку інших драматичних сюжетів, об'єднаних темою становлення християнства від перших років виникнення до організації світової релігійної спільноти. При ознайомленні $з$ цим твором стає очевидним, що перед нами повноцінна п’єса, яка темою, ідеєю та глибиною конфліктів має емоційний відгук у сучасного українського глядача. Події твору розгортаються в рік страти Ісуса Христа і характеризують надзвичайно напружені стосунки між імперським Римом і його колонією Галілеєю. Поява у Єрусалимі людини, яка своїми проповідями та етичним прикладом поведінки заволоділа душами знедолених верств єврейського народу, не на жарт налякала імперську окупаційну владу. Ідея Царства Божого заперечувала нероздільну владу римського імператора і ставила під загрозу всю систему управління єврейською державою. Тож імперські емісари блискавично зреагували на виклики часу. 3 іншого боку - місцева правляча еліта не бажала втратити нагоду збагатитись ціною зради інтересів свого народу. Саме таким діячем єврейської імперської правлячої еліти постає помічник тетрарха Галілеї Хуса. Від його дій залежить не лише близьке оточення, а й доля народу, за спиною якого нечисті на руку державні діячі вирішують доленосні питання. Говорячи су- 
часною мовою, Хуса задумав здійснити державний переворот, а саме, подавши донос імператорові, змістити тетрарха та посісти його місце. Обставини, що склалися в колонії, сприяють намірам Хуси. Тож тема твору - взаємодія еліт Риму та Галілеї на тлі виникнення нової релігії. Єврейська держава уже давно втратила незалежність. Ця обставина $\epsilon$ домінантною у п'єсі. Галілеєю правлять лояльні до імперської влади представники древніх єврейських родів, що проводять в життя колоніальну політику стосовно свого народу.

Для визначення наскрізної дії п'єси виокремимо конкретні сценічні події. Перша серед них - сцена зібрання підлеглих Хуси, в якій господар дає суворі розпорядження щодо приготувань до зустрічі поважних гостей з Риму. В події обов'язково має відбутись щось важливе для подальшого розвитку сюжету та конфлікту п’єси. Тож і в цьому разі, внаслідок взаємодії господаря 3 обслугою, стає очевидним, що прийняти гостей на належному рівні неможливо. Дружина Хуси Йоганна якийсь час тому покинула чоловіка, повірила у вчення Христа і разом з іншими однодумцями помандрувала за проповідником. У покинутій оселі немає ладу. До того ж, за римським звичаєм, не годиться відвідувати будь-чий дім, якщо в ньому відсутня господиня. Однак у разі зриву візиту римських гостей на кар'єру Хуси чекає крах — це домінанта події. Виникає проблема 3 пошуком особи, яка б замінила дружину. Хуса плекає надію на допомогу матері.

Наступна подія містить у собі спробу Хуси домовитись 3 матір'ю щодо їі участі у святковому прийомі. У сина з матір'ю давній і непримиренний конфлікт на грунті релігійних та патріотичних позицій. Це - домінанта події. Але Мелхола, жінка вихована в національних традиціях неприйняття окупаційної влади та чужої культури, рішуче відмовляється йти на компроміс зі своїми переконаннями. Більш того, вона засуджує наміри сина. Хуса гостро відчув небезпеку свого становища і згоден вислухати від матері будь-які докори. Але суперечності у сина з матір'ю настільки серйозні, що домогтися домовленості не вдалося. Хуса відчайдушно шукає спосіб вирішення нагальної проблеми і готовий вдатися до відвертої авантюри.

Проблема перетікає у наступну подію. Хусі не залишається вибору, і він примушує коханку Сабіну зіграти роль дружини. Але Сабіна — paбиня і має свої далекоглядні плани щодо стосунків з господарем. Це - домінанта події. Коханка погоджується на обман тільки в разі оголошення себе дружиною Хуси. Ціна за послугу надто висо- ка. Господар не погоджується і готовий покарати непокірну на смерть. Ситуація набуває рис безвиході. Проблема вирішується у наступній події.

Несподіване повернення Йоганни змінює розстановку сил і створює нові можливості для Хуси. Послуги рабині втрачають актуальність. Зіткнення життєвих позицій чоловіка і дружини формують наступну подію, у якій Хуса брутально ламає опір дружини і майже силоміць примушує її прийняти гостей з Риму. Йоганна стала християнкою і за своїми переконаннями мусить коритися чоловікові. Це - домінанта події. Хуса підкоряє волю непокірної дружини і примушує іiі допомогти у вирішенні завдання, що стоїть перед ним. Хусі вдалося подолати всі негативні для нього обставини, і тепер прийому гостей ніщо не загрожує.

Наступна подія - прийом Публія та Марції. Вона складається $з$ двох частин, але об'єднана конкретною дією. Хуса вже не бореться за можливість здійснити свій злочинний намір, а догоджає в усьому гостям та намагається їм будь-що сподобатись. Він переконливо демонструє вірність імператору та любов до всього римського світу. Публій та Хуса уособлюють негативні людські якості, 3 півслова розуміють один одного і відчувають потребу у злочинній співпраці - ця обставина є домінантою. У першій частині події Хуса здійснює донос на тетрарха, а в другій дає хабара Марції. В результаті він отримує запрошення до Риму. Тобто відбувається реалізація наскрізної дії п'єси, яку очолює Хуса.

Але Л. Українку цікавить не тема здійснення цинічної авантюри, а щось інше, більш суттєве і важливе. Авторка ставить проблему свободи особистості і свободи віри. Успіх зради свого законного господаря і підкупу римських емісарів відбувається за мовчазної і пасивної позиції Йоганни, яка розуміє, що чоловік творить зло. Ї̈̈ моральні і духовні сили паралізовані заповідями вчителя. Драматургиня не ставить явного акценту, а віддає право судити вчинки героїв твору глядачеві.

Ідея твору: державні мужі, які зраджують інтереси свого народу,- небезпечні. Їх дії потрібно пильно відстежувати та контролювати.

Надзавдання п'єси лежить у сфері усвідомлення значення релігійних почуттів у боротьбі за свободу людської особистості, яку Л. Українка ставить на перше місце.

Тож, визначивши першорядні події, потрібно поставити смислові та емоційні акценти з урахуванням розвитку наскрізної дії та основного конфлікту п'єси.

Частина роботи 3 організації темпо-ритму вистави припадає на період творчого задуму. 
Творчий задум вистави - процес надзвичайно складний, багатогранний та в чомусь непередбачуваний. Але обов'язково його формування та реалізація опиратимуться на моменти аналізу всіх компонентів художнього твору. В цьому разі здійснюється спроба організації конкретно наскрізної дії через формування темпо-ритму вистави.

Після того, як проведений аналіз п'єси та виокремлені події, слід через практичні проби 3 акторами визначитись із темпо-ритмом у кожній події, про що наголошувалося вище. Саме ця практична робота і має забезпечити майбутню конфігурацію темпо-ритму вистави через розставлення смислових та емоційних акцентів.

Наскрізна дія п'єси реалізується не в усіх подіях, а в першорядних. Подія, в якій запускається механізм розвитку конфлікту та сюжету надзвичайно важлива саме для глядача. Актори, які працюють над виставою, добре знають обставини та смисл взаємодії в цій події, а от глядачеві необхідно подати всі компоненти чітко, виразно і без поспіху. Сильні емоційні сплески тут будуть не до місця. Інакше частина глядачів, менш підготовлених до художнього сприйняття, опиниться поза зоною співпереживання і не стане співучасницею вистави.

Наскрізна дія не виникає за межами п'єси i «не падає з неба». Вона формується в певній події на очах у глядача. Тож режисер і актори мають подбати про це важливе місце у композиції творчого задуму через загострення уваги глядача та підвищення емоційності дії акторами.

Наскрізна дія обов'язково набуде найбільшого емоційного розвитку в певній події. Це саме той момент, де можна і необхідно використати всі засоби сценічної виразності, а саме: високий темпо-ритм взаємодії, виразна мізансцена, психологічно наповнена пауза, музика, світло тощо.

Наскрізна дія вистави - це боротьба когось із кимось і за щось. Тобто дійова особа або група осіб, котрі очолюють дію, долають спротив своїх опонентів заради досягнення бажаної мети. Будьяка боротьба опонентів закінчується або перемогою або поразкою. Іншими словами, наскрізна дія вистави вичерпує себе в конкретній події.

Головна подія п'єси стоїть немовби відокремлено від магістральної лінії боротьби і не є продовженням наскрізної дії. Вона $€$ іiі результатом і завершує основний конфлікт.

Як приклад, можна звернутись до аналізу п'єс, створених у різних історичних умовах та культурних традиціях. Зокрема, до трагедії В. Шекспіра «Ромео і Джульєтта» та комедії М. Гоголя «Ревізор». У трагедії В. Шекспіра наскрізну дію очо- люють Ромео і Джульєтта в устремлінні реалізації свого кохання. Домінантною обставиною трагедії $€$ одвічна ворожнеча родів Монтеккі та Капулетті. Головна подія трагедії розгортається вже після смерті молодих героїв. Втративши найдорожче дітей, ворогуючі колись родини миряться. В. Шекспір звертає нашу увагу на ту високу ціну, яку заплатило європейське суспільство на шляхах гуманізації людських стосунків. У комедії М. Гоголя «Ревізор» наскрізну дію очолює Сквозник-Дмухановський з компанією однодумців і полягає вона в тому, щоб перехопити ревізора зі столиці, купити його і зробити безпечним для чиновницької братії. Місто, де обжилася компанія злочинців на державних посадах, «пограбоване до нитки»-це домінантна обставина комедії. Справжній ревізор прибуває в момент розгубленості й розчарування городничого та його поплічників, що й паралізує волю останніх і унеможливлює здатність до результативного опору - це головна подія комедії. М. Гоголь наголошує на принципі невідворотності покарання за скоєні злочини.

Таким чином, темпо-ритм вистави - це композиція побудови наскрізної дії у подіях драматургічного твору, що забезпечує вирішення основного конфлікту п'єси у напрямку реалізації надзавдання вистави. Гармонійне співвідношення смислових та емоційних акцентів у подіях вистави створить цільну художню форму, яка, з одного боку, твориться акторським ансамблем, а з іншого - забезпечує сприйняття глядачами творчого задуму.

Універсального закону відбору запропонованих обставин не існує, тож той чи інший постановник буде вибудовувати сценічну подію з позицій власного творчого досвіду, своїх естетичних уподобань та певного рівня театральної культури. Тож сучасний театр пропонує нам різні за змістом та формою вистави одних і тих самих п’єс.

У тих театральних системах, де сценічна дія не $\epsilon$ метою і засобом реалізації сценічної задачі - темпом буде часовий вимір перебігу творчого процесу, а ритмом - чергування моментів напруження та послаблення тих чи інших складових театрального видовища.

\section{Джерела та література}

1. Великий тлумачний словник сучасної української мови (з дод., допов. та CD) / Уклад. і голов. ред. В. Т. Бусел. Київ; Ірпінь: ВТФ «Перун», 2009. 1736 с.

2. Музыкальная энциклопедия / Гл. ред. Ю. В. Келдыш. Москва: Сов. энциклопедия. 1981. Т. 5. С. 491.

3. Музыкальная энциклопедия / Гл. ред. Ю. В. Келдыш. Москва: Сов. энциклопедия. 1981. Т. 4. С. 657-658. 
4. Станиславский К. С. Собр. соч.: в 8 т. Москва: Гос. изд-во «Искусство». 1954-1961. Т. 3. 500 с.

5. Театральная энциклопедия: в 5 т. Москва: Сов. энциклопедия. 1965. Т. 4. С. 619.

6. Лесь Курбас. Філософія театру. Київ: Вид-во Соломії Павличко «Основи». 2001. С. 248.

\section{References}

1. Velykyy tlumachnyy slovnyk suchasnoyi ukrayins'koyi movy (z dod., dopov. ta CD) / Uklad. i holov. red. V. T. Busel (2009). Kyev; Irpin': VTF «Perun». 1736 s. [in Ukrainian].
2. Muzykal'naya éntsyklopedyya / H1. red. YU. V. Keldysh (1981). Moskva: Sov. éntsyklopedyya. T. 5. S. 491 [in Russian].

3. Muzykal'naya éntsyklopedyya / Hl. red. YU. V. Keldysh (1981). Moskva: Sov. éntsyklopedyya. T. 4. S. 657-658 [in Russian].

4. Stanyslavskyi K. S. Sobranye sochynenyy v 8 t. (1954-1961) Moskva: Hos. izd-vo. «Iskusstvo». T. 3. 500 s. [in Russian].

5. Teatral'naya éntsyklopedyya: v 5 t. (1965). Moskva: Sov. éntsyklopedyya. T. 4. S. 619 [in Russian].

6. Les' Kurbas. Filosofiya teatru (2001). Kyev: Vyd-vo Solomiyi Pavlychko «Osnovy». S. 248 [in Ukrainian]. 